\section{Preparation of Milk-clotting Enzyme from Basidiomycete}

\section{Eiichi KikuchI ${ }^{*}$, Hideyuki Kobayashi **, Hiroshi Shibuya ${ }^{* *}$, Isao Kusakabe ${ }^{* *}$ and Kazuo MuraKami ** \\ * Research Division, Snow Brand Milk Products Co. Ltd., 13 Honshio-cho, Shinjuku-ku, Tokyo 160 \\ ** Institute of Applied Biochemistry, University of Tsukuba, 1-1-1 Tennohdai,} Tsukuba-shi, Ibaraki 305

In the selection of rennet substitutes, it is well known that the ratio of milk-clotting activity to proteolytic activity (MCA/PA) is an important index and higher $\mathrm{MCA} / \mathrm{PA}$ ratio is desirable. Thus, a simple preparation method was investigated for the elimination of proteinase having high proteolytic activity from the rennet-like enzyme of Irpex lacteus. At the treatment of $\mathrm{pH} 6.5,35^{\circ} \mathrm{C}$ for $20 \mathrm{~min}$, the proteinase other than the milkclotting enzyme was inactivated almost completely and the MCA/PA ratio increased approximately 1.8-fold over that of the crude preparation. This value closely equaled that of the milk-clotting enzyme of Irpex lacteus, purified by an affinity chromatography. It is concluded that this advantageous treatment can be easily applied commercially for cheese manufacture, because it is very simple and cheap.

Cultured filtrate of Irpex lacteus, a basidiomycete, contains milk-clotting enzyme and proteinase with high proteolytic activity. Although both enzymes belong to the aspartic proteinase which has optimum $\mathrm{pH}$ at the acidic region, the milk-clotting enzyme is inhibited completely by pepstatin ${ }^{122)}$, a specific aspartic proteinase inhibitor, at a concentration of $10^{-5} \mathrm{M}^{3)}$, whereas the co-existing proteinase is not affected by pepstatin at all even at a concentration of $10^{-3} \mathrm{M}^{4}$. We have already reported $^{1)}$ that the milk-clotting enzyme is separated from the contaminated proteinase by affinity chromatography having a pepstatin derivative as a ligand. We have also made a Cheddar cheese with the milk-clotting enzyme fraction of Irpex lacteus purified by affinity chromatography and have shown a possibility of using the milk-clotting enzyme as a calf rennet substitute by comparing it with the cheese made with calf rennet ${ }^{5}$. However, it is too expensive to apply affinity chromatography to get the milk-clotting enzyme fraction on a large scale.

In this paper, we report a simple method for inactivating the proteinase having high proteolytic activity to get the milk-clotting enzyme.

\section{Materials and Methods}

\section{Materials}

Calf rennet powder was purchased from $\mathrm{Chr}$. Hansen Lab. Denmark and Mucor pusillus rennet was obtained from Meito Sangyo Co. Ltd. Japan. Pepstatin was obtained from Protein Research Foundation of Japan, hemoglobin was purchased from Sigma Chemical Co., and casein was from Merck. SVP (distiller's soluble, Sun Grain) was obtained from Suntory, Ebios was from Asahi Breweries Co. Ltd. and Nonion E-230 was from Nihon Yushi Co. Ltd.

Enzyme assays

Milk-clotting and proteolytic activities were measured as described in our previous paper ${ }^{3}$.

Estimation of pepstatin inhibition

To $0.99 \mathrm{ml}$ of enzyme solution, $10 \mu l$ of pepstatin solution $\left(10^{-2} \mathrm{M} / \mathrm{DMF}\right)$ was added and the mixture was immersed in an ice bath for $15 \mathrm{~min}$. Then the remaining activity was determined with hemoglobin as the substrate at $\mathrm{pH} 3.0$ and $35^{\circ} \mathrm{C}$ for $30 \mathrm{~min}$. The pepstatin inhibition was calculated as follows,

pepstatin inhibition $(\%)=(A-B) / A \times 100$

$A$ : proteolytic activity without pepstatin

$B:$ proteolytic activity with pepstatin

Media and culture conditions

The seed medium contained $4 \%$ sucrose, $3 \%$ SVP (distiller's soluble), $0.3 \%$ yeast extract, $0.5 \% \mathrm{KH}_{2} \mathrm{PO}_{4}, 0.05 \% \mathrm{MgSO}_{4} \cdot 7 \mathrm{H}_{2} \mathrm{O}$, and the $\mathrm{pH}$ of the medium was adjusted to 4.0 . The production medium contained $6 \%$ sucrose, $3 \%$ SVP, $\quad 0.6 \%$ Ebios, $\quad 0.6 \% \mathrm{NH}_{4} \mathrm{H}_{2} \mathrm{PO}_{4}, \quad 0.05 \%$ 
$\mathrm{MgSO}_{4} \cdot 7 \mathrm{H}_{2} \mathrm{O}, 0.1 \%$ lactic acid, $1 \mathrm{ppm}$ calcium pantothenate, $10 \mathrm{ppm}$ choline chloride, 0.2 $\%$ Nonion $\mathrm{E}-230$, and the $\mathrm{pH}$ of the medium was adjusted to 3.8 . Seed culture was carried out in $500 \mathrm{~m} l$ flasks containing $60 \mathrm{~m} l$ of seed medium at $30^{\circ} \mathrm{C}$ for $4 \sim 5$ days at $125 \mathrm{opm}$. Enzyme production was conducted in a 5 liter jar fermentor containing 2 liters of production medium at $28^{\circ} \mathrm{C}$. Agitation and aeration was kept at $750 \mathrm{rpm}$ and $0.5 \mathrm{vvm}$, respectively.

\section{Results and Discussion}

Production of the enzyme began after $50 \mathrm{~h}$ cultivation, and the enzyme activity reached maximum at $120 \mathrm{~h}$ fermentation. Then the cultured broth was centrifuged at $9000 \times \mathrm{g}$ for $15 \mathrm{~min}$, and ammonium sulfate was added to the supernatant to bring $80 \%$ saturation. The resultant precipitate was collected by centrifugation and dissolved in small quantities of water. The solution was dialyzed against $0.01 \mathrm{M}$ acetate, pH 5.5, and used as crude enzyme solution during the subsequent studies.

The crude enzyme solution contains milkclotting enzyme and pepstatin-insensitive aspartic proteinase having high proteolytic activity. It is possible to determine the content of the milk-clotting enzyme in the crude enzyme preparation, because the milk-clotting enzyme is inhibited by pepstatin at the concentration of $10^{-4} \mathrm{M}$ completely, whereas the proteinase is not affected at all at the same concentration ${ }^{4)}$. Thus, the remaining proteolytic activity at $\mathrm{pH}$ 3.0 after the treatment with pepstatin indicates the activity of pepstatin-insensitive aspartic proteinase.

Analysis of this pepstatin-insensitive aspartic proteinase revealed that the ratio of milkclotting activity to proteolytic activity on casein at $\mathrm{pH} 6.0$ was one-fourth of that of the milk-clotting enzyme and one-second of that of the crude enzyme. To determine the optimum condition for eliminating the pepstatininsensitive aspartic proteinase, the stability of the milk-clotting enzyme and of the proteinase was investigated. After the treatment at conditions of $30^{\circ} \mathrm{C}$ for $1 \mathrm{~h}$ at various $\mathrm{pHs}$, the milk-clotting enzyme was stable between $\mathrm{pH} 3$ to 6 , whereas the proteinase was stable between $\mathrm{pH} 3$ to 5 . It is obvious that the proteinase is relatively less stable at neutral $\mathrm{pH}$ region than the milk-clotting enzyme.

To select the condition suitable for inactivating the proteinase in the crude preparation ; $\mathrm{pH}$, temperature and incubation time was changed, and then the remaining proteolytic activity at $\mathrm{pH} 3$ and pepstatin inhibition were measured. If the proteinase is inactivated completely, the pepstatin inhibition must in-

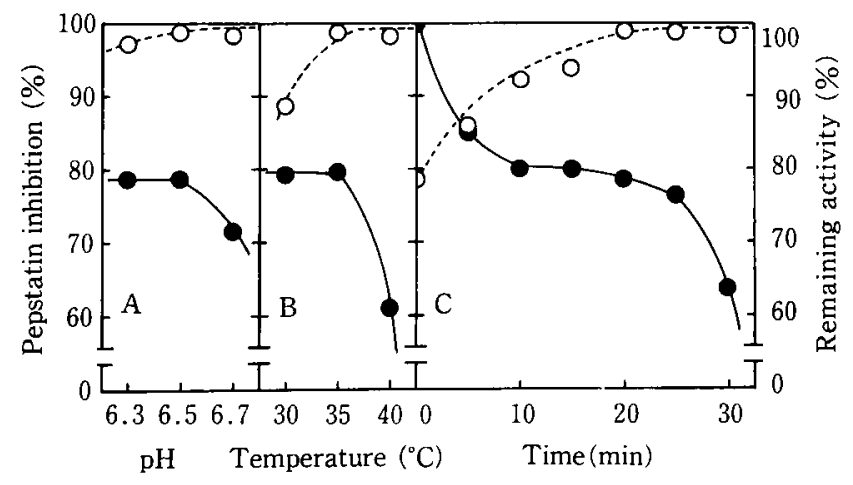

Fig. 1 Effects of heat treatment on pepstatin inhibition and the stability of the crude enzyme

The experimental conditions were the following: $A$, at various pHs and $35^{\circ} \mathrm{C}$ for $20 \mathrm{~min}$; $\mathrm{B}$, at various temperatures and $\mathrm{pH} 6.5$ for $20 \mathrm{~min} ; \mathrm{C}$, at $35^{\circ} \mathrm{C}$ and $\mathrm{pH} 6.5$ for various time intervals. $\mathrm{O}$, pepstatin inhibition; remaining activity. 
Table 1 Effect of heat treatment on milk-clotting activity to proteolytic activity (MCA/PA) ratio and pepstatin inhibition of the crude enzyme

\begin{tabular}{|c|c|c|c|c|}
\hline & Pepstatin inhibition( $(\%)^{*}$ & $\mathrm{MCA}(\mathrm{su} / \mathrm{m} l)$ & PA(unit)** & $\mathrm{MCA} / \mathrm{PA}$ \\
\hline $\begin{array}{l}\text { Heat } \\
\text { treatment*** }\end{array}$ & 99.4 & 1791 & 1.9 & 943 \\
\hline Control**** & 77.0 & 1832 & 3.5 & 523 \\
\hline
\end{tabular}

* The remaining activity was determined using $1.2 \%$ hemoglobin ( $\mathrm{pH} 3.0$ ) as substrate at $35^{\circ} \mathrm{C}$ for $30 \mathrm{~min}$ after the treatment with $10^{-4} \mathrm{M}$ pepstatin at $0^{\circ} \mathrm{C}$ for $15 \mathrm{~min}$.

** The proteolytic activity was determined using $1.2 \%$ casein $\left(\mathrm{pH} 6.0\right.$ ) as substrate at $35^{\circ} \mathrm{C}$ for 30 min.

*** Heat treatment of $\mathrm{pH} 6.5$ and $30^{\circ} \mathrm{C}$ for $20 \mathrm{~min}$

**** Treatment of $\mathrm{pH} 6.5$ and $0^{\circ} \mathrm{C}$ for $20 \mathrm{~min}$

crease to $100 \%$ and the proteolytic activity at $\mathrm{pH} 3$ remains at about $80 \%$ of the control. By the treatment of $35^{\circ} \mathrm{C}$ for $20 \mathrm{~min}$, pepstatin inhibition reached the level of nearly $100 \%$ from pH 6.3 to 6.7 (Fig. 1-A). But the optimum $\mathrm{pH}$ for inactivating the proteinase was found to be from 6.3 to 6.5 , because the remaining activity by the treatment at $\mathrm{pH} 6.7$ was less than those at $\mathrm{pH} 6.3$ and $\mathrm{pH} 6.5$ treatments. When the crude enzyme was incubated at $\mathrm{pH} 6.5$ for $20 \mathrm{~min}$ at various temperatures, almost complete pepstatin inhibition was observed above $35^{\circ} \mathrm{C}$ (Fig. 1-B). In the incubation at $40^{\circ} \mathrm{C}$, the proteolytic activity decreased to less than $70 \%$ of the original activity, indicating that not only proteinase but also milkclotting enzyme was inactivated above $40^{\circ} \mathrm{C}$. When the crude enzyme was incubated at $\mathrm{pH}$ 6.5 and $35^{\circ} \mathrm{C}$, the pepstatin inhibition rate increased to nearly $100 \%$ at $20 \mathrm{~min}$ incubation (Fig. 1-C). At this stage, the proteolytic activity was shown to be $80 \%$ of the control, after that the proteolytic activity decreased further with prolonged incubation time. Thus, the optimum condition for treating the Irpex crude enzyme was determined to be at $\mathrm{pH} 6.5$ and $35^{\circ} \mathrm{C}$ for $20 \mathrm{~min}$.

After incubating the crude enzyme with the condition suitable for the elimination of proteinase, i.e. incubation at $\mathrm{pH} 6.5$ and $35^{\circ} \mathrm{C}$ for $20 \mathrm{~min}$, the residual activity with pepstatin treatment was reduced from $23 \%$ to $1 \%$ of the original activity (Table I). This fact indicates that the proteinase existing in the crude preparation is inactivated almost completely by the heat treatment. In addition, the MCA/PA ratio increased 1.8 -fold by this treatment over the crude preparation. This value closely equals that of the milk-clotting enzyme fraction of Irpex lacteus obtained from affinity chromatography ${ }^{3)}$. The decrease of the milkclotting activity was less than $3 \%$ of the original activity, indicating that the milk-clotting enzyme was still fully active after the treatment. It is suggested that this advantageous treatment can be easily scaled up commercially for cheese manufacture, because it is really simple and cheap. Evaluation of heat-treated enzyme by actual cheese making test will be published elsewhere.

\section{References}

1) Umezawa, H., Aoyagi, T., Morishima, H., Matsuzaki, M., Hamada, H. and TakeUCHI, T. : J. Antibiot., 23, 259 (1970).

2) Morishima, H., Takita, T., Aoyagi, T., Takeuchi, T. and Umezawa, H. : J. Antibiot., 23, 263 (1970).

3) Kobayashi, H., Kusakabe, I. and MurakaMI, K. : Agric. Biol. Chem., 47, 551 (1978).

4) Kobayashi, H., Kusakabe, I. and MuraKami, K.: Agric. Biol. Chem., 49, 2393 (1985).

5) Kobayashi, H., Kusakabe, I. and MuraкAMI, K.: Agric. Biol. Chem., 49, 1605 (1985).

(Received Jun. 18, 1987) 


\section{担子菌凝乳酳素の調慜}

菊池栄一 ${ }^{*}$. 小林秀行 ${ }^{* *}$ ・ 渋谷浩司**

日下部功 ${ }^{* *}$ - 村上和雄 ${ }^{* *}$

*雪印乳業株式会社研究本部

(F 160 東京都新宿区本塩町 13 番地)

** 筑波大学応用生物化学系

（干 305 茨城県つくば市天王台 1-1-1）

体レンネット代替品を選択する際, タンパク分解活 性に対する数乳活性の比（MCA/PA）は重要な指標で
あり，より高い MCA/PA 比が望まれる。をこで, Irpex lacteus のレンネット様酵素から, 高いタンパク分 解力をむつプロテアーゼを除去するための簡単な凝乳醉 素調製法を研究した. $\mathrm{pH} 6.5,35^{\circ} \mathrm{C}, 20 \mathrm{~min}$ の処理で, 凝乳酵素以外のプロテアーゼははぼ完全に失活し，MCA/ PA 比は粗酵素標品の約 1.8 倍に上昇した. この值は, アフィニティークロマトグラフィーで精製されたIrpex lacteus の凝乳酵素の值亡よく似ていた．この処理法は 簡単で安価であり，チーズ製造工業に容易に応用できる と結論される。 